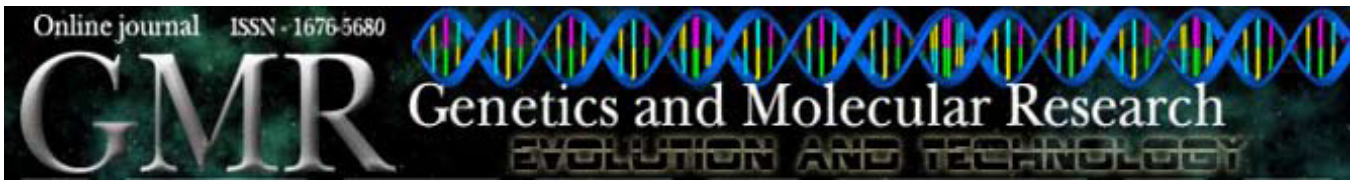

\title{
Isolation and characterization of the promoter sequence of a cassava gene coding for Pt2L4, a glutamic acid-rich protein differentially expressed in storage roots
}

\author{
C.R. de Souza ${ }^{1}$, F.J. Aragão ${ }^{2}$, E.C.O. Moreira ${ }^{1}$, C.N.M. Costa ${ }^{1}$, \\ S.B. Nascimento ${ }^{1}$ and L.J. Carvalho ${ }^{2}$ \\ ${ }^{1}$ Laboratório de Biologia Molecular, Universidade Federal do Pará, \\ Belém, PA, Brasil \\ ${ }^{2}$ Embrapa Recursos Genéticos e Biotecnologia, Brasília, DF, Brasil \\ Corresponding author: C.R. de Souza \\ E-mail: bsouza@ufpa.br
}

Genet. Mol. Res. 8 (1): 334-344 (2009)

Received December 1, 2008

Accepted February 4, 2009

Published March 24, 2009

\begin{abstract}
Cassava is one of the most important tropical food crops for more than 600 million people worldwide. Transgenic technologies can be useful for increasing its nutritional value and its resistance to viral diseases and insect pests. However, tissuespecific promoters that guarantee correct expression of transgenes would be necessary. We used inverse polymerase chain reaction to isolate a promoter sequence of the Mecl gene coding for Pt2L4, a glutamic acid-rich protein differentially expressed in cassava storage roots. In silico analysis revealed putative cis-acting regulatory elements within this promoter sequence, including root-specific elements that may be required for its expression in vascular tissues. Transient expression experiments showed that the $\mathrm{Mecl}$ promoter is
\end{abstract}


functional, since this sequence was able to drive GUS expression in bean embryonic axes. Results from our computational analysis can serve as a guide for functional experiments to identify regions with tissue-specific $\mathrm{Mecl}$ promoter activity. The DNA sequence that we identified is a new promoter that could be a candidate for genetic engineering of cassava roots.

Key words: Cassava; Pt2L4 glutamic acid-rich protein; In silico analysis; Inverse polymerase chain reaction; Root promoter; Transient expression

\section{INTRODUCTION}

Cassava (Manihot esculenta Crantz) belongs to the family Euphorbiaceae, is native to South America, and is one of the most important tropical food crops for more than 600 million people worldwide. Basically, every part of the plant can be utilized, but roots are the most commonly used product. In developing countries, cassava roots are very often the sole source of calories.

Storage roots develop from primary roots through cell division and differentiation of parenchyma cells of the secondary xylem (Rateaver, 1951; Castilloa et al., 1997). An anatomical model with three tissue compartmentalization systems has been used in gene expression studies (De Souza et al., 2002, 2006). According to this model, tissue system I is composed of phellogen and phelloderm, tissue system II of phloem and vascular cambium, and tissue system III of secondary xylem with its highly specialized starch-rich parenchyma cells.

Pt2L4 is an alcohol-soluble protein predominately expressed in tissue system III, which contains secondary xylem and parenchyma cells with starch granules (De Souza et al., 2002). The deduced amino acid composition of the Pt2L4 protein revealed that the most abundant amino acids are glutamic acid (31.6\%), alanine (16.94\%), valine (13.55\%), and proline (11.29\%) (De Souza et al., 2006). Pt2L4 and C54 proteins are 60\% identical with similar molecular weights (16.7 and $18.0 \mathrm{kDa}$, respectively) and isoelectric points (3.70 and 3.97) (Zhang et al., 2003; De Souza et al., 2006). There are two or more homologous genes coding for glutamic acid-rich proteins in the cassava genome according to Southern blot analysis (Zhang et al., 2003; De Souza et al., 2006). Studies have revealed that their transcripts are most strongly expressed in vascular tissues and in parenchyma cells of storage roots, indicating an important role in storage root formation (Zhang et al., 2003; De Souza et al., 2004, 2006). In addition, Zhang et al. (2003) reported greatest C54 promoter activity in vascular cambium and starch-rich parenchyma cells of storage roots from transgenic cassava plants containing this promoter fused to the $\beta$-glucuronidase (GUS) reporter gene.

Despite recent advances in the isolation and characterization of endogenous promoters from cassava, only a few tissue- and organ-specific promoters have been identified. The identification of tissue-specific promoters is essential for genetic engineering of cassava, which has been used to increase nutritional value of roots, as well as to produce plants with enhanced resistance to viral diseases and insect pests and with reduced cyano- 
genic content (Taylor et al., 2004).

In this study, we report the isolation and characterization of a promoter sequence of $\mathrm{Mecl}$ gene coding for Pt2L4, a glutamic acid-rich protein differentially expressed in storage roots. In silico analyses revealed some putative cis-acting regulatory elements and transcription factor-binding sites within this promoter sequence, such as root-specific elements. Results about the $\mathrm{Mec} 1$ promoter functionality are presented.

\section{MATERIAL AND METHODS}

\section{Plant material}

Cassava (Manihot esculenta Crantz) leaves were kindly provided by Dr. Eloisa Cardoso from EMBRAPA Amazônia Oriental (EMBRAPA-CPATU, Belém, PA, Brazil).

\section{Promoter sequence isolation by inverse polymerase chain reaction}

Genomic DNA was isolated from cassava leaves using a Purelink Plant Total DNA Purification Kit and quantified using a Qubit fluorimeter, both supplied by Invitrogen Life Technologies, following manufacturer instructions.

Samples containing about $10 \mu \mathrm{g}$ genomic DNA were totally and separately digested with HaeIII, DraI, and HphI restriction enzymes. After phenol:chloroform:isoamyl alcohol (24:24:1) extractions and ethanol precipitation, DNA fragments were self-circularized by $\mathrm{T}_{4}$ DNA ligase and used in inverse polymerase chain reaction (PCR). Two reverse primers (Mec2-R: 5'actggctctgcttccttgggctcttc3' and Mec3-R: 5'tcctcaggaagtgcagtctgtgctgt3') and one forward primer (Mec4-F: 5'gctgatgatgctccggctgaagtagc3') were designed according to the $\mathrm{Mec} 1 \mathrm{cDNA}$ sequence previously isolated and registered in the NCBI GenBank (accession No. AY101376).

DNA fragments were amplified using Mec2-R/Mec4-F primers in the primary inverse PCR and Mec3-R/Mec4-F primers in the secondary inverse PCR. The conditions used in primary and secondary inverse PCR assays were: 5 min at $94^{\circ} \mathrm{C}, 30$ amplification cycles $\left(1 \mathrm{~min}\right.$ at $94^{\circ} \mathrm{C}, 1 \mathrm{~min}$ at $63^{\circ} \mathrm{C}$, and $1.5 \mathrm{~min}$ at $\left.72^{\circ} \mathrm{C}\right)$ and $20 \mathrm{~min}$ at $72^{\circ} \mathrm{C}$ for a final extension. PCR assays were carried out using an Advantage 2 polymerase mix kit supplied by Clontech (Palo Alto, USA). Amplified products were purified from an agarose gel using a QIAquick Spin kit (Qiagen) and cloned into the pGEMTeasy vector system (Promega Corporation).

PCR assays using Mec9-F (5'ggtgatgagaagagagactatttcgttgaca3') and Mec11-R (5'tacctcagcagtagccatagtcagcca3') primers were conducted to obtain a contiguous promoter sequence, which was amplified from non-digested genomic DNA and cloned into the pGEMTeasy vector system generating the pMec1 plasmid. All clones were sequenced using a Megabace Sequencer 1000 (GE Healthcare Life Sciences).

\section{Sequence analysis}

Nucleotide sequences were aligned using the BLAST algorithm (Altschul et al., 1997) and the ClustalW program (Thompson et al., 1994). The TFSearch program was 
used for searching putative transcription factor-binding sites (Heinemeyer et al., 1998). PlantCARE and PLACE Databases were used to determine plant cis-acting regulatory elements (Prestridge, 1991; Higo et al., 1999; Lescot et al., 2002).

\section{Constructs used in transient expression experiments}

The 800-bp fragment containing the $35 \mathrm{~S}$ promoter was released from the plasmid pCAMBIA 3201 (CAMBIA, Canberra, Australia) by digestion with BamHI and NcoI. Primers Mec12-F (agggatccggtgatgagaagagagactatttcg) and Mec13-R (cagtagccatggtcagcca) containing BamHI and NcoI sites (underlined) were used to amplify the 970-bp Mecl promoter from the pMec1 plasmid. After digestions with these two enzymes, the 952-bp fragment was cloned between the BamHI and NcoI sites from pCAMBIA 3201, replacing the 35S CaMV promoter, which generated the pCAMBIA-Mec1 plasmid. As a negative control, the $800-\mathrm{bp}$ fragment containing the 35S promoter was released from the plasmid pCAMBIA 3201 by digestion with BamHI and NcoI, and the DNA fragment vector was then self-circularized by $\mathrm{T}_{4}$ DNA ligase. As a positive control we used the pCAMBIA 3201.

\section{Bombardment of bean embryonic axes}

Explant preparation and particle bombardment were carried out according to previously described methods (Aragão et al., 1996). Bean embryonic axes were surface and transversally bombarded separately with three plasmids: pCAMBIA-Mec1, pCAMBIA 3201 and pCAMBIA 3201 with deleted CaMV 35S promoter. After bombardment (50 $\mu \mathrm{mol} \cdot \mathrm{m}^{-2} \cdot \mathrm{s}^{-1}$ ), explants were cultivated for $24 \mathrm{~h}$ at $28^{\circ} \mathrm{C}$ with a $16-\mathrm{h}$ photoperiod on MS medium. Tissues were analyzed for in situ localization of GUS activity according to methods described elsewhere (Jefferson et al., 1987).

\section{RESULTS AND DISCUSSION}

\section{Isolation of $\mathrm{Mec} 1$ promoter sequence by inverse polymerase chain reaction}

Our goal in this study was to isolate a promoter sequence of $\mathrm{Mecl}$ gene differentially expressed in storage roots of cassava by inverse PCR. The ability to drive gene expression in a tissue-specific manner is an important factor in transgenic crop biotechnology.

To achieve this goal, genomic DNA samples were digested with HaeIII, HphI, and DraI, self-circularized by $\mathrm{T}_{4}$ DNA ligase, and used in inverse PCR. Figure 1 depicts a partial sequence of $\mathrm{Mecl}$ cDNA (GenBank accession No. AY101376) indicating the primer sequences used in inverse PCR. Restriction enzymes HaeIII and HphI cut the Mecl cDNA sequence at 309- and 632-bp positions, respectively, while there is no site for DraI within this sequence.

DNA fragments with 350,1400 , and 1500 bp were amplified by inverse PCR using genomic DNA digested with HaeIII, DraI and HphI, respectively, according to analysis on an agarose gel electrophoresis (data not shown). A 970-bp fragment was amplified from non-digested genomic DNA by conventional PCR using Mec9-F/Mec11-R primers. 
Comparative sequence analysis showed that all amplified fragments corresponded to the genomic sequences of the $\mathrm{Mecl}$ cDNA.

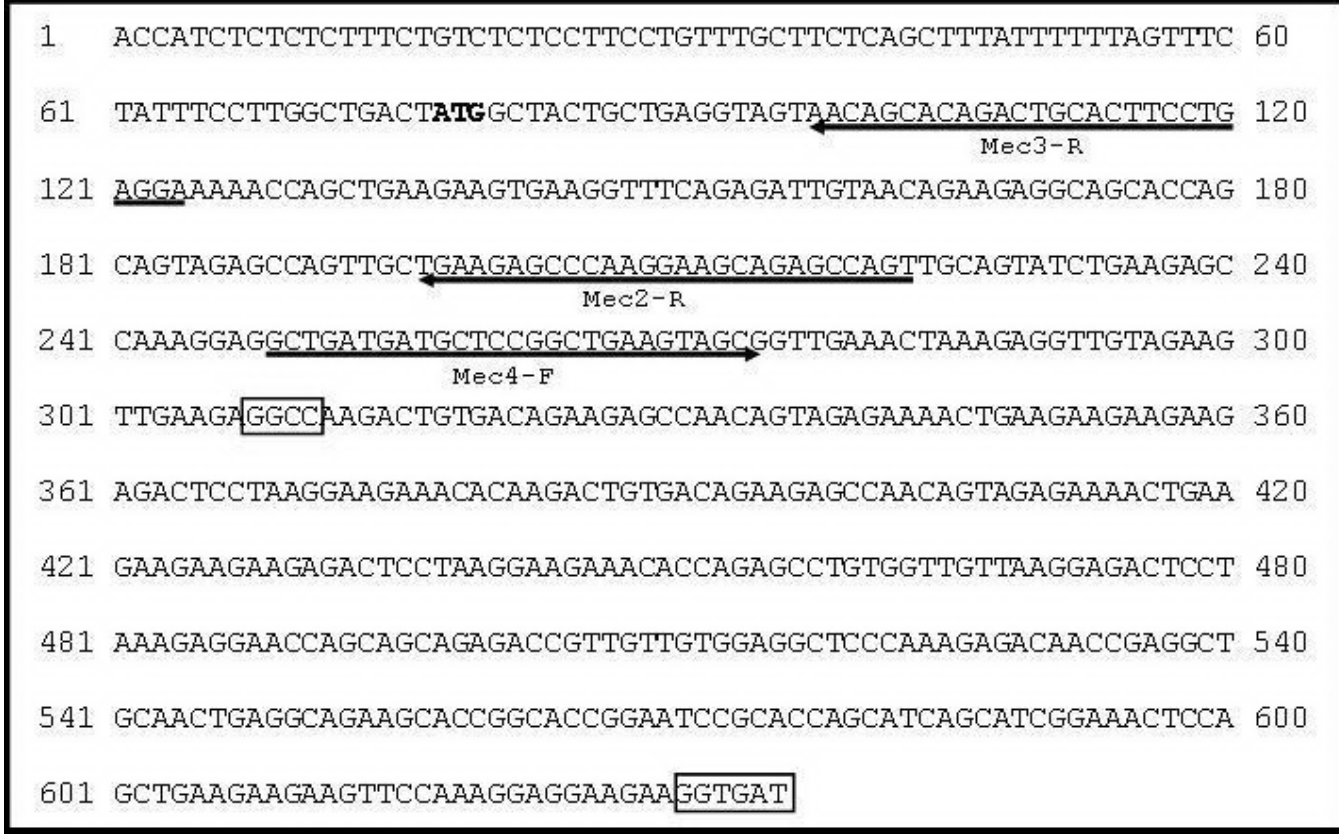

Figure 1. Partial sequence of Mecl cDNA (accession No. AY101376) with Mec2-R, Mec3-R and Mec4-F primers used in inverse polymerase chain reaction. Initiator ATG is in bold. HaeIII and HphI sites are boxed.

In Figure 2, the final genomic sequence of $\mathrm{Mecl}$ gene is depicted, as obtained here and registered in the NCBI GenBank (Accession No. FJ688171). The fragment amplified from genomic DNA digested with HaeIII contained 37 bp downstream from Mec4-F primer and $282 \mathrm{bp}$ upstream from Mec3-R primer. This 282-bp sequence contains a very short promoter sequence (49 bp) due to the presence of one site for this enzyme (GGCC) located at $121 \mathrm{bp}$ upstream from initiator ATG. In addition, an intron sequence with $136 \mathrm{bp}$ was identified by comparison with cDNA sequence (Figure 2). The fragment amplified from genomic DNA digested with DraI contained $737 \mathrm{bp}$ downstream from Mec4-F primer and $677 \mathrm{bp}$ upstream from Mec3-R primer, while the fragment obtained from genomic DNA digested with $H p h$ I contained 361 bp downstream from Mec4-F primer and 1109 bp upstream from Mec3-R primer. Comparative sequence analysis showed that all sequences amplified upstream from Mec3-R primer and downstream from Mec4-F matched with the Mecl cDNA sequence previously isolated.

PCR assays using Mec9-F/Mec11-R primers generated a contiguous genomic DNA fragment that contains the $\mathrm{Mecl}$ promoter sequence (Figure 2), confirming that the inverse PCR methodology was efficient in the isolation of this promoter. 


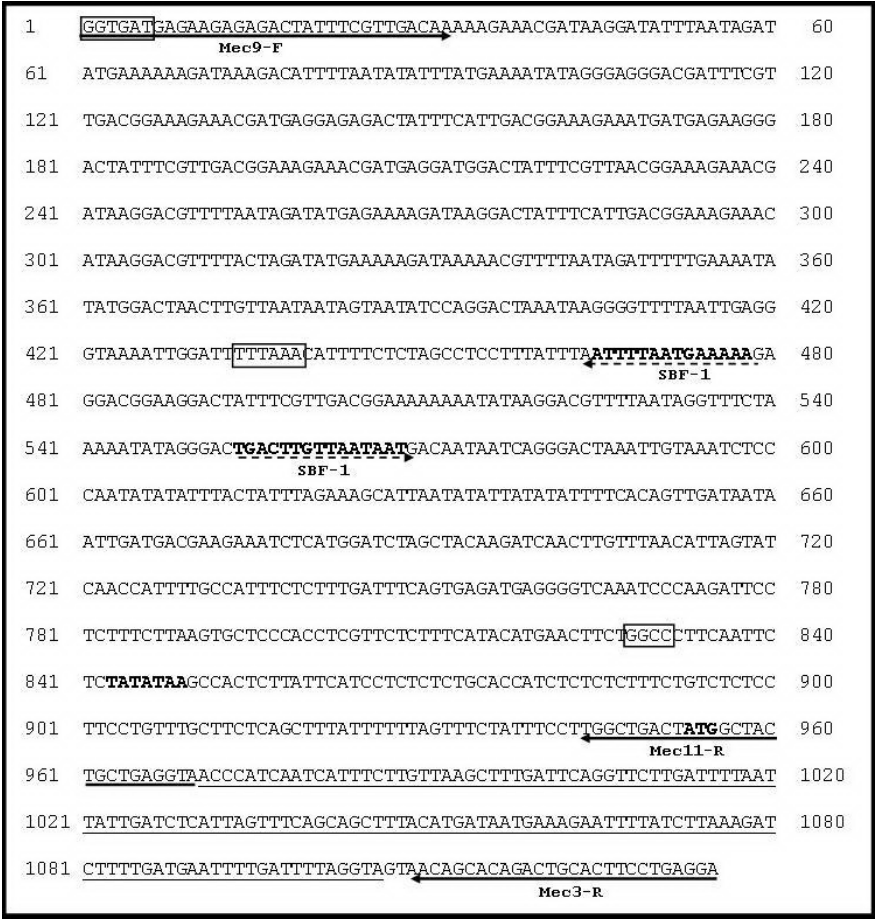

Figure 2. Genomic sequence of Mecl cassava gene (GenBank accession No. FJ688171) with Mec3-R, Mec9-F and Mec11-R primers' positions. Start codon and TATA-box are in bold. Intron sequence is underlined. Sites for HaeIII, DraI and HphI enzymes are boxed. Bold letters underlined with dashed arrows indicate putative SBF-1 binding sites.

\section{In silico analysis of the Mec1 promoter sequence}

Cis-acting regulatory elements are important molecular switches involved in the transcriptional regulation of a dynamic network of gene activities controlling various biological processes, such as response to hormones and abiotic stress and developmental processes. In silico analysis has been used with success in the identification of putative regulatory elements in plant promoters (Wei-Min et al., 2005; Pujade-Renaud et al., 2005). In order to identify putative transcription factor binding sites and conserved plant cis-acting regulatory elements, the 952-bp Mecl promoter sequence was analyzed using TFSearch algorithm and PlantCARE and PLACE databases.

Analysis using TFSearch algorithm with a threshold score of 86.8 revealed two putative binding sites for SBF-1 within $\mathrm{Mecl}$ promoter sequence (Figure 2). SBF-1 protein regulates chalcone synthase gene expression in maize (Lawton et al., 1991), an enzyme that catalyzes the first reaction specific for the biosynthesis of flavonoid compounds, which have important functions in the development of the plant and in interactions with its environment.

Sequence analysis showed that a TATA box (TATATAA) is located $103 \mathrm{bp}$ upstream from initiator ATG (Figure 2). Many known regulatory elements were identified in Mecl promoter (Table 1); some of these were also found in C54 promoter sequence, such as many lightresponsive elements and binding sites for SBF-1 (Zhang et al., 2003). 
Table 1. Putative cis-acting regulatory elements identified in the Mecl promoter by in silico analysis search against PlantCARE (PC) and PLACE (P) databases.

\begin{tabular}{|c|c|c|c|c|}
\hline Element & Database (ID) & Position & Strand & Expected function \\
\hline A-box & $\mathrm{PC}$ & 480 & - & Cis-acting regulatory element \\
\hline \multirow[t]{2}{*}{ ACE-box } & $\mathrm{PC}$ & 332 & + & Cis-acting element involved in light responsiveness \\
\hline & & 435 & - & \\
\hline AE-box & $\mathrm{PC}$ & 294 & + & Part of a module for light response \\
\hline Box-I & $\mathrm{PC}$ & 350 & - & Light responsive element \\
\hline Box-4 & $\mathrm{PC}$ & 626 & + & Part of a conserved DNA module involved in light responsiveness \\
\hline \multirow[t]{8}{*}{ CAAT-box } & $\mathrm{PC}$ & 153 & - & Common cis-acting element in promoter and enhancer regions \\
\hline & & 424 & - & \\
\hline & & 570 & + & \\
\hline & & 587 & - & \\
\hline & & 599 & + & \\
\hline & & 600 & + & \\
\hline & & 660 & - & \\
\hline & & 834 & + & \\
\hline CAT-box & $\mathrm{PC}$ & 849 & + & Meristem expression \\
\hline CCGTCC-box & $\mathrm{PC}$ & 480 & - & Meristem specific activation \\
\hline \multirow[t]{6}{*}{ CGTCA-motif } & $\mathrm{PC}$ & 120 & - & Methyl jasmonate responsiveness \\
\hline & & 155 & - & \\
\hline & & 190 & - & \\
\hline & & 286 & - & \\
\hline & & 500 & - & \\
\hline & & 665 & - & \\
\hline GAG-motif & $\mathrm{PC}$ & 877 & - & Part of a light responsive element \\
\hline \multirow[t]{3}{*}{ GATA-motif } & $\mathrm{PC}$ & 37 & + & Part of a light responsive element \\
\hline & & 236 & + & \\
\hline & & 266 & + & \\
\hline I-box & $\mathrm{PC}$ & 268 & + & Part of a light responsive element \\
\hline MBS & $\mathrm{PC}$ & 648 & - & MYB binding site involved in drought-inducibility \\
\hline \multirow[t]{2}{*}{ Skn-1-motif } & $\mathrm{PC}$ & 566 & - & Endosperm expression \\
\hline & & 664 & - & \\
\hline Sp1 & $\mathrm{PC}$ & 103 & - & Light responsive element \\
\hline TC-rich repeats & $\mathrm{PC}$ & 440 & + & Cis-acting element involved in defense and stress responsiveness \\
\hline \multirow[t]{2}{*}{ Circadian } & $\mathrm{PC}$ & 112 & - & Cis-acting regulatory element involved in circadian control \\
\hline & & 696 & - & \\
\hline SPBF TACTATT-motif & $\mathrm{P}(\mathrm{S} 000184)$ & 612 & + & SPBF binding site required by sporamin storage root expression \\
\hline \multirow[t]{5}{*}{ ATATT-motif } & $\mathrm{P}(\mathrm{S} 000098)$ & 48 & + & Expression in roots \\
\hline & & 87 & + & \\
\hline & & 607 & + & \\
\hline & & 633 & + & \\
\hline & & 640 & + & \\
\hline \multirow[t]{9}{*}{ AAAG-motif } & $\mathrm{P}(\mathrm{S} 000265)$ & 33 & + & Core site required for binding of Dof proteins \\
\hline & & 67 & + & \\
\hline & & 162 & + & \\
\hline & & 197 & + & \\
\hline & & 232 & + & \\
\hline & & 267 & + & \\
\hline & & 326 & + & \\
\hline & & 476 & + & \\
\hline & & 622 & + & \\
\hline \multirow[t]{4}{*}{ CTCTT-motif } & $\mathrm{P}(\mathrm{S} 000468)$ & 738 & + & Element characteristic of the promoters activated in infected cells of root \\
\hline & & 806 & + & nodules \\
\hline & & 854 & + & \\
\hline & & 884 & + & \\
\hline
\end{tabular}

The orientation of elements is indicated (+, forward; -, reverse). 
According to our previous results, $\mathrm{Mecl}$ transcript is predominately found in secondary xylem and starch-rich parenchyma cells of storage roots, and Pt2L4 is a protein involved in secondary growth of the underground storage organ (De Souza et al., 2006). Interestingly, several ATATT-motifs required for vascular expression in roots (Elmayan and Tepfer, 1995) were identified in the $\mathrm{Mecl}$ promoter gene. These motifs were initially found in the promoter of rolD genes, which are preferentially expressed in roots compared to leaves, and more specifically in the root elongation zone and vascular tissue. ATATT-motifs were also found in two promoters from Hevea brasiliensis that showed an expression in vascular tissues of roots in transgenic rice (Pujade-Renaud et al., 2005). A root-specific regulatory element was also identified in the Mec 1 promoter, such as an SPBF-binding site, required by sporamin gene expression, a major protein in tuberous roots of Ipomea batatas (Ishiguro and Nakamura, 1992, 1994).

Based on the expression pattern of the Mecl gene (De Souza et al., 2004, 2006), we can hypothesize that putative cis-acting regulatory elements found in the $\mathrm{Mecl}$ promoter modulate its gene expression in vascular cambium and starch-rich parenchyma cells, participating in some mechanisms related to secondary growth. Storage roots develop from primary roots through cell division and differentiation of parenchyma cells of the secondary xylem, which is differentiated from meristematic cells of vascular cambium (Rateaver, 1951; Castilloa et al., 1997). According to Northern blot experiments of five different tissue layers of cassava storage root (L1 to L5), Mec1 expression initiates in L2, composed of phloem and vascular cambium (De Souza et al., 2006). In addition, we found no Mecl expression in stem peel, which contains phloem.

Another regulatory element identified in $\mathrm{Mecl}$ promoter sequence is the CTCTT-motif found in promoters activated in infected cells of root nodules (Vieweg et al., 2004; Fehlberg et al., 2005). Since some cellular and molecular processes occurring during storage root formation are also common features found in nodulation/tumorigenesis-related tissues (You et al., 2003), it is possible that in cassava these elements are important for mechanisms related to root tuberization. Also, we found that Pt2L4 protein has $44 \%$ of identity with ag 13 protein (data not shown) expressed in the pericycle of the nodule vascular bundle of Alnus glutinosa (Guan et al., 1997).

The AAAG-motif is a core site required for binding of Dof proteins, a type of zinc finger regulatory protein that plays diverse roles in plants (Yanagisawa and Schmidt, 1999; Yanagisawa, 2000). Recent studies have revealed a potential role of zinc finger proteins in storage root formation in cassava and sweet potato, showing that their genes are developmentally regulated during this process (De Souza et al., 2004; Tanaka et al., 2005).

\section{Functional evaluation of the Mec1 promoter by transient expression experiments}

Transient expression experiments have been efficiently used in the functional evaluation of plant promoter sequences (Loake et al., 1991; Bansal et al., 1992; Chibbar et al., 1993; Pinto et al., 2002).

In order to analyze the activity of the promoter sequence isolated here, the pCAMBIAMec1 construct was generated, which contains the GUS reporter gene under Mecl promoter control. The germinating bean embryonic axes were then bombarded with this construct and GUS activity was analyzed by in situ localization. GUS expression under $\mathrm{Mecl}$ promoter control was histochemically determined in vascular tissue, stem pith and epidermal cells of embryonic axes $24 \mathrm{~h}$ after particle bombardment (Figure 3). On the other hand, no GUS activity was visualized in embryonic axes bombarded with the pCAMBIA 3201 plasmid with the 35 S promoter deleted, our negative control. 


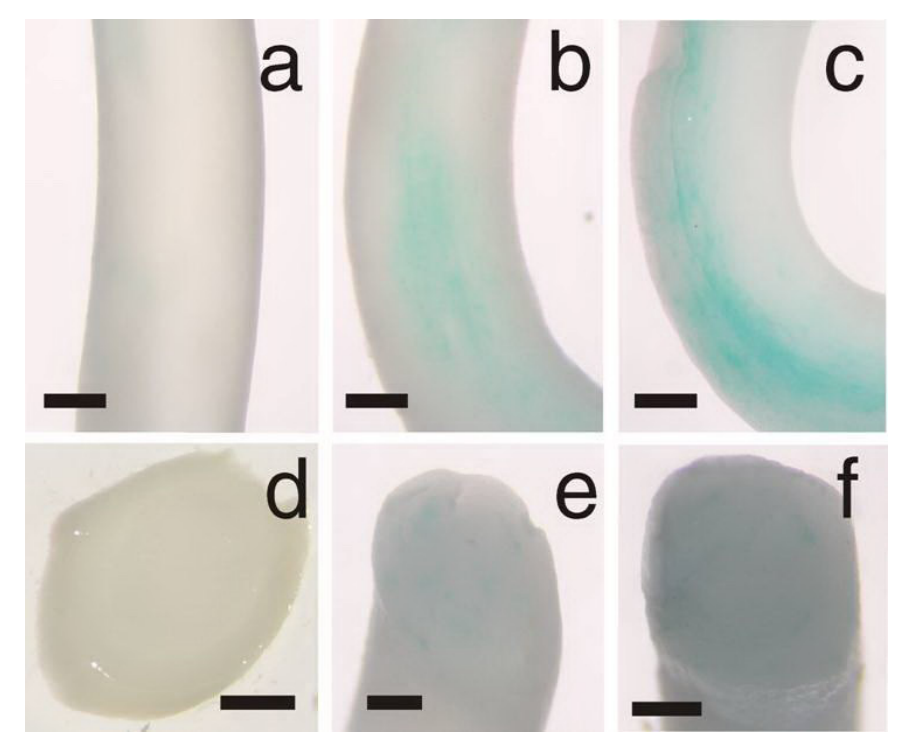

Figure 3. Detection of GUS activity in bean embryonic axes bombarded with the pCAMBIA-Mec1 (b, e, f), pCAMBIA 3201 (c) and pCAMBIA 3201 with deleted 35 S promoter (a, d). Bars $=0.5 \mathrm{~mm}$.

This result showed that the 952-bp fragment from the cassava Mecl promoter is long enough and that it also contains enhancers and regulatory elements, such as TATA and CAATbox and box regulatory elements related to meristem activation and expression, necessary to ensure GUS expression in this heterologous system. Interestingly, a distinct pattern of GUS activity was observed in the central region (vascular tissues) of bean embryonic axes bombarded with pCAMBIA-Mec1 plasmid in contrast to the constitutive 35S CaMV promoter, where the most expression was found in epidermal and parenchymal cells. This observation indicates a tissue-specific pattern of this root-promoter, which is consistent with our previous results demonstrating that the $\mathrm{Mecl} \mathrm{cDNA}$ is preferentially expressed in secondary xylem (De Souza et al., 2004, 2006) and that several ATATT-motifs are required for vascular expression in roots identified by in silico analysis. However, additional studies are essential to elucidate the functions of these elements in the tissue-specificity of the $\mathrm{Mecl}$ promoter sequence.

\section{CONCLUSIONS}

In this study, the isolation and characterization of a promoter sequence of $\mathrm{Mecl}$ gene coding for the Pt2L4 glutamic acid-rich protein of cassava was reported. Results obtained from transient expression experiments showed that this promoter sequence is functional, and therefore, it is suitable for further experiments, including stable genetic transformation of model plants. In addition, the results obtained from computational analysis can serve as a guide to establish these functional experiments in order to identify regions exhibiting a tissuespecific $\mathrm{Mecl}$ promoter activity. The DNA sequence identified here is a new promoter that can be a potential candidate for genetic engineering of cassava roots. 


\section{ACKNOWLEDGMENTS}

Research supported by Secretaria Executiva de Ciência e Tecnologia do Estado do Pará (SECTAM/FUNTEC-PA, Brazil), Departamento de Ciência e Tecnologia, da Secretaria de Ciência, Tecnologia e Insumos Estratégicos do Ministério da Saúde (Brazil), Conselho Nacional de Desenvolvimento Científico e Tecnológico (Brazil), Coordenação de Aperfeiçoamento de Pessoal de Nível Superior (Brazil), and Cassava Biotechnology Network (CBNSmall Grant Program, Cali, Colombia).

\section{REFERENCES}

Altschul SF, Madden TL, Schaffer AA, Zhang J, et al. (1997). Gapped BLAST and PSI-BLAST: a new generation of protein database search programs. Nucleic Acids Res. 25: 3389-3402.

Aragão FJL, Barros LMG, Brasileiro ACM, Ribeiro SG, et al. (1996). Inheritance of foreign genes in transgenic bean (Phaseolus vulgaris L.) co-transformed via particle bombardment. Theor. Appl. Genet. 93: 142-150.

Bansal KC, Viret JF, Haley J, Khan BM, et al. (1992). Transient expression from cab-m1 and rbcS-m3 promoter sequences is different in mesophyll and bundle sheath cells in maize leaves. Proc. Natl. Acad. Sci. U. S. A. 89: 3654-3658.

Castilloa JJ, Castilloa A and Pino LT (1997). Notas sobre histología foliar y radical en yuca (Manihot esculenta Crantz). In: La Yuca Frente al Hambre del Mundo Tropical, Universidad Central de Venezuela, Caracas, 77-100.

Chibbar RN, Kartha KK, Dalta RSS, Leung N, et al. (1993). The effect of different promoter-sequences on transient expression of GUS reporter gene in cultured barley (Hordeum vulgare L.) cells. Plant Cell Rep. 12: 506-509.

De Souza CR, Carvalho LJ, De Almeida ER and Gander ES (2002). Towards the identification of cassava root protein genes. Plant Foods Hum. Nutr. 57: 353-363.

De Souza CR, Carvalho LJ and de Mattos Cascardo JC (2004). Comparative gene expression study to identify genes possibly related to storage root formation in cassava. Protein Pept. Lett. 11: 577-582.

De Souza CR, Carvalho LJ, De Almeida ER and Gander ES (2006). A cDNA sequence coding for a glutamic acid-rich protein is differentially expressed in cassava storage roots. Protein Pept. Lett. 13: 653-657.

Elmayan T and Tepfer M (1995). Evaluation in tobacco of the organ specificity and strength of the rolD promoter, domain A of the 35S promoter and the 35S2 promoter. Transgenic Res. 4: 388-396.

Fehlberg V, Vieweg MF, Dohmann EM, Hohnjec N, et al. (2005). The promoter of the leghaemoglobin gene VfLb29: functional analysis and identification of modules necessary for its activation in the infected cells of root nodules and in the arbuscule-containing cells of mycorrhizal roots. J. Exp. Bot. 56: 799-806.

Guan C, Akkermans ADL, Kammen A, van Bisseling T, et al. (1997). ag13 is expressed in Alnus glutinosa nodules in infected cells during endosymbiont degradation and in the nodule pericycle. Physiol. Plantarium 99: 601-607.

Heinemeyer T, Wingender E, Reuter I, Hermjakob H, et al. (1998). Databases on transcriptional regulation: TRANSFAC, TRRD and COMPEL. Nucleic Acids Res. 26: 362-367.

Higo K, Ugawa Y, Iwamoto M and Korenaga T (1999). Plant cis-acting regulatory DNA elements (PLACE) database: 1999. Nucleic Acids Res. 27: 297-300.

Ishiguro S and Nakamura K (1992). The nuclear factor SP8BF binds to the 5'-upstream regions of three different genes coding for major proteins of sweet potato tuberous roots. Plant Mol. Biol. 18: 97-108.

Ishiguro S and Nakamura K (1994). Characterization of a cDNA encoding a novel DNA-binding protein, SPF1, that recognizes SP8 sequences in the 5' upstream regions of genes coding for sporamin and beta-amylase from sweet potato. Mol. Gen. Genet. 244: 563-571.

Jefferson RA, Kavanagh TA and Bevan MW (1987). GUS fusions: beta-glucuronidase as a sensitive and versatile gene fusion marker in higher plants. EMBO J. 6: 3901-3907.

Lawton MA, Dean SM, Dron M, Kooter JM, et al. (1991). Silencer region of a chalcone synthase promoter contains multiple binding sites for a factor, SBF-1, closely related to GT-1. Plant Mol. Biol. 16: 235-249.

Lescot M, Dehais P, Thijs G, Marchal K, et al. (2002). PlantCARE, a database of plant cis-acting regulatory elements and a portal to tools for in silico analysis of promoter sequences. Nucleic Acids Res. 30: 325-327.

Loake GJ, Choudhary AD, Harrison MJ, Mavandad M, et al. (1991). Phenylpropanoid pathway intermediates regulate transient expression of a chalcone synthase gene promoter. Plant Cell 3: 829-840.

Pinto AA, Coelho MCF, Souza MT Jr and Guerra MP (2002). Transient expression of the GUS gene, under the regulation of four promoters, on different tissues of papaya (Carica papaya L.) and grape (Vitis sp.). Rev. Bras. Frutic. 24: 787-789.

Genetics and Molecular Research 8 (1): 334-344 (2009)

CFUNPEC-RP www.funpecrp.com.br 
Prestridge DS (1991). SIGNAL SCAN: a computer program that scans DNA sequences for eukaryotic transcriptional elements. Comput. Appl. Biosci. 7: 203-206.

Pujade-Renaud V, Sanier C, Cambillau L, Pappusamy A, et al. (2005). Molecular characterization of new members of the Hevea brasiliensis hevein multigene family and analysis of their promoter region in rice. Biochim. Biophys. Acta 1727: 151-161.

Rateaver B (1951). Anatomy and Regeneration in the Stem and Root of Manihot utilissima Pohl. Doctoral thesis, University of Michigan, Ann Arbor, 1-100.

Tanaka M, Takahata Y and Nakatani M (2005). Analysis of genes developmentally regulated during storage root formation of sweet potato. J. Plant Physiol. 162: 91-102.

Taylor N, Chavarriaga P, Raemakers K, Siritunga D, et al. (2004). Development and application of transgenic technologies in cassava. Plant Mol. Biol. 56: 671-688.

Thompson JD, Higgins DG and Gibson TJ (1994). CLUSTAL W: improving the sensitivity of progressive multiple sequence alignment through sequence weighting, position-specific gap penalties and weight matrix choice. Nucleic Acids Res. 22: 4673-4680.

Vieweg MF, Fruhling M, Quandt HJ, Heim U, et al. (2004). The promoter of the Vicia faba L. leghemoglobin gene VfLb29 is specifically activated in the infected cells of root nodules and in the arbuscule-containing cells of mycorrhizal roots from different legume and nonlegume plants. Mol. Plant Microbe Interact. 17: 62-69.

Wei-Min L, Zhi-Xing W, Xin-Wu P and Shi-Rong J (2005). Cloning and characterization of the light-inducible Gacab promoter from Gossypium arboreum. Agric. Biotechnol. 2: 17-22.

Yanagisawa S (2000). Dof1 and Dof2 transcription factors are associated with expression of multiple genes involved in carbon metabolism in maize. Plant J. 21: 281-288.

Yanagisawa S and Schmidt RJ (1999). Diversity and similarity among recognition sequences of Dof transcription factors. Plant J. 17: 209-214.

You MK, Hur CG, Ahn YS, Suh MC, et al. (2003). Identification of genes possibly related to storage root induction in sweet potato. FEBS Lett. 536: 101-105.

Zhang P, Bohl-Zenger S, Puonti-Kaerlas J, Potrykus I, et al. (2003). Two cassava promoters related to vascular expression and storage root formation. Planta 218: 192-203. 